\title{
Escravidão e liberdade: o paradoxo americano
}

\author{
EDMUND S. MORGAN
}

$\mathrm{O}$

$S$ HISTORIADORES americanos que buscam as origens do surgimento da liberdade, da democracia, e o homem comum tiveram de enfrentar, nas duas últimas décadas, o desafio lançado por outros historiadores que têm interesse na origem da história da opressão, exploração e racismo. Esse desafio tem sido salutar porque nos levou a examinar, de um modo mais direto do que os historiadores até o presente se haviam predisposto a fazer, o papel da escravidão no início de nossa história. Sobretudo os historiadores do período colonial, ao escreverem sobre a origem e desenvolvimento das instituições norte-americanas, até recentemente achavam maneiras de tratar a escravidão como

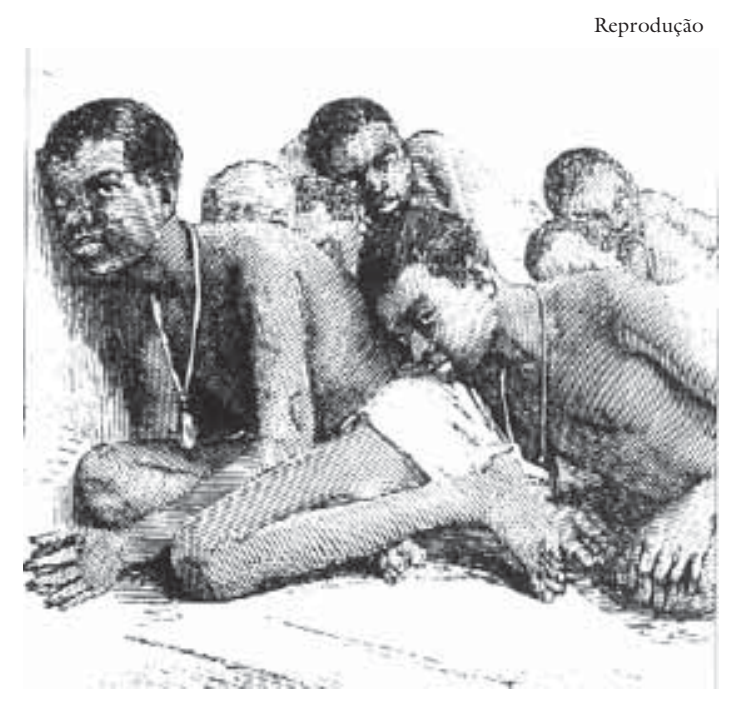

A posição em que escravos eram transportados uma exceção a tudo o que tinham a dizer. Estou falando de mim mesmo e também da maioria dos integrantes de minha geração. Devemos gratidão àqueles que insistiram no fato de ter sido a escravidão mais que uma exceção; que um quinto da população americana na época da Revolução é gente demais para ser tratada como exceção (1).

O desafio não será superado simplesmente estudando-se a história desse quinto, por mais frutífero e urgente que tal estudo possa ser. Também não superaremos o desafio pela mera execução da conhecida manobra de virar nossas velhas interpretações de cabeça para baixo. Já se percebe a tentação de argumentar que a escravidão e a opressão foram as marcas dominantes da história americana e que os esforços para fazer avançar a liberdade e a igualdade foram a exceção, de fato nada mais do que um recurso para desviar a atenção das massas enquanto se prendiam seus grilhões. Tratar o 
surgimento da liberdade e da igualdade na história americana como mera hipocrisia não é apenas ignorar fatos concretos; é também evadir-se do problema que tais fatos apresentam. O surgimento da liberdade e da igualdade no país foi acompanhado pelo surgimento da escravidão. $O$ fato de que duas evoluções tão contraditórias ocorressem simultaneamente durante um largo tempo, do século XVII ao XIX, constitui o paradoxo central da história americana.

O desafio, pelo menos para um historiador do período colonial, está em explicar como um povo pôde desenvolver a dedicação à liberdade e dignidade humanas mostrada pelos próceres da Revolução americana e, ao mesmo tempo, desenvolver e manter um sistema de trabalho que negava essa liberdade e dignidade a cada hora do dia.

O paradoxo é evidente em muitos níveis se quisermos vê-lo. Pensemos, por exemplo, na tradicional insistência na liberdade dos mares. $\mathrm{O}$ axioma "Navios livres fazem mercadoria livre" era o ponto cardeal da doutrina americana em política externa à época da Revolução. Mas a mercadoria para a qual os Estados Unidos exigiam liberdade era produzida em grande parte pelo trabalho escravo. A ironia é mais que semântica. A dependência americana do trabalho escravo deve ser vista no contexto da luta do país por uma posição independente e igual no âmbito das nações da Terra.

$\mathrm{Na}$ época em que os colonizadores anunciaram sua reivindicação a essa posição, não dispunham nem de armas nem de navios para fazer valer sua exigência. Precisaram desesperadamente pedir a colaboração de outros países, sobretudo da França, e seu único produto de mais valor para comprar a colaboração era o tabaco, produzido principlamente pelo trabalho escravo. Era tão grande a importância desse produto nas relações internacionais que um historiador se referiu às atividades da França em apoio aos americanos como "Diplomacia do rei Tabaco", fazendo lembrar que a posição dos Estados Unidos no mundo, não apenas em 1776 mas durante o período de uma longa vida após essa data, dependeu do trabalho escravo (2). Pode-se dizer que em grande parte os americanos compraram sua independência com trabalho escravo.

O paradoxo torna-se mais agudo se pensarmos no estado de onde provinha a maior parte do tabaco. A Virgínia à época do primeiro censo dos Estados Unidos em 1790 tinha 40\% dos escravos de todo o país. E a Virgínia produziu os mais eloqüentes porta-vozes da liberdade e igualdade de todo o país: George Washington, James Madison e, principalmente, Thomas Jefferson. Todos eles eram donos de escravos e assim permaneceram durante toda a vida. Nos últimos anos mostrou-se em tristes detalhes o contraste 
entre os pronunciamentos de Jefferson a favor da liberdade republicana e sua cumplicidade na negação dos benefícios dessa liberdade para os negros (3). Sentiu-se a tentação de descartar Jefferson e toda a dinastia da Virgínia como hipócritas. Mas isso seria privar o termo hipocrisia de um significado útil. Se hipocrisia significa, como eu suponho, deliberadamente afirmar princípios em que não se acredita, então a hipocrisia requer uma rara clareza mental combinada com a intenção inescrupulosa de enganar. Atribuir essa intenção, ou mesmo atribuir essa clareza mental sobre o assunto, a Thomas Jefferson, Madison ou Washingon significa novamente evitar o desafio. O que precisamos explicar é como esses homens puderam chegar a crenças e atos tão cheios de contradições.

Coloquemos o paradoxo de outra forma: como foi que a Inglaterra, um país orgulhoso da liberdade de seus cidadãos, produziu colônias onde a maioria dos habitantes desfrutava de ainda mais liberdade, mais oportunidades e de um maior controle sobre suas próprias vidas em relação à maioria dos homens na pátria-mãe, enquanto o restante da população, um quinto do total, era virtualmente privado de qualquer liberdade, quaisquer oportunidades, qualquer controle sobre a própria vida? Podemos admitir que os ingleses que colonizaram a América e seus descendentes revolucionários eram racistas e, consciente ou inconscientemente, acreditavam que liberdades e direitos deveriam restringir-se a pessoas de pele clara. Dito isto, mesmo depois de analisar as profundezas do preconceito racial, não significa que tenhamos explicado completamente o paradoxo. O racismo foi com certeza um elemento essencial do paradoxo, mas eu gostaria de sugerir outro elemento, que acredito ter influenciado a evolução tanto da escravidão quanto da liberdade como as conhecemos nos Estados Unidos.

Comecemos com Jefferson, esse porta-voz da liberdade que era dono de escravos. Será que no tipo de liberdade por ele acalentada havia algo que o teria levado a aceitar, apesar de toda a relutância, a escravidão de tantos americanos? A resposta, na minha opinião, é sim. A liberdade defendida por Jefferson não era um dom a ser conferido por governos, nos quais na melhor das hipóteses ele não confiava. Era uma liberdade que surgia da independência do indivíduo. O homem que dependesse de outro para viver jamais poderia ser realmente livre. Podemos buscar a pista da enigmática postura de Jefferson frente à escravidão em sua atitude para com aqueles que desfrutavam de liberdade aparente sem a necessária independência para sustentá-la. Com relação a tais pessoas Jefferson alimentava uma profunda desconfiança, que encontrou expressão em duas fobias as quais repontam aqui e acolá em seus escritos. 
O primeiro indício era uma profunda aversão a dívidas. Embora a economia da Virgínia dependesse da dupla disposição dos senhores de plantations de contrair dívidas e dos comerciantes ingleses de estender o crédito; embora o próprio Jefferson tenha sido um devedor a vida inteira ou talvez por isso mesmo - ele odiava dívidas e odiava tudo o que o tornasse um devedor. E o odiava porque isso limitava sua liberdade. Não poderia, por exemplo, libertar seus escravos enquanto estivesse endividado. Ou pelos menos era assim que ele pensava. Mas não era simplesmente o impedimento à liberdade deles mas à sua própria que o atormentava. "Sinto-me infeliz", escreveu ele, "até que não deva nem um centavo ..." (4).

O fato de ter ele muitos companheiros de infelicidade apenas agravava o problema. Sua Declaração da Independência dos Estados Unidos foi ridicularizada pelo controle que os comerciantes ingleses mantiveram sobre os devedores norte-americanos, incluindo ele mesmo (5). Sua hostilidade contra Alexander Hamilton enraizava-se no reconhecimento de que a política externa pró-britânica de Hamilton reforçaria o controle dos credores ingleses, ao passo que a sua política interna colocaria o governo como devedor de uma classe de credores nativos americanos, cujo poder poderia se tornar igualmente pernicioso.

Mesmo sendo a preocupação de Jefferson com o malefício das dívidas quase obsessiva, ela estava plenamente de acordo com as idéias de liberdade republicana que compartilhava com seus patrícios. O problema das dívidas era que, solapando a independência do devedor, elas ameaçavam a liberdade republicana. Sempre que dívidas submetiam um cidadão ao poder de outro, o devedor perdia mais do que sua própria liberdade de ação. Também enfraquecia a capacidade de seu país de sobreviver como república. Segundo um axioma do pensamento político da época, o governo republicano exigia um corpo de cidadãos livres, independentes e proprietários (6). Uma nação de cidadãos, cada um dos quais tivesse uma propriedade suficiente para sustentar sua família, poderia ser uma república. A conseqüência lógica era que uma nação de devedores, que tivessem perdido sua propriedade ou que a tivessem hipotecado a credores, estava madura para a tirania. Jefferson, por conseqüência, apoiava todos os meios de impedir o endividamento dos cidadãos e manter a propriedade amplamente distribuída. Insistia na abolição da primogenitura e da transmissão hereditária, declarando que a terra pertencia aos vivos e não lhes deveria ser tirada por dívidas ou credores dos mortos; que teria doado 50 acres de terra a cada americano sem terra - tudo porque acreditava que eles só poderiam ser livres se fossem economicamente livres em virtude da posse da terra com que pudessem se sustentar (7). 
Se Jefferson tinha sentimentos tão profundos sobre a servidão, não surpreende que detectasse um perigo para a república em outra classe de cidadãos que, como os devedores, eram nominalmente livres mas cuja independência era ilusória. A segunda fobia de Jefferson era sua desconfiança contra os trabalhadores urbanos sem terra empregados em fábricas. $\mathrm{Na}$ visão de Jefferson, eles eram homens livres apenas nominalmente. É famosa sua hostilidade por artesãos, geralmente atribuída à sua preferência romântica pela vida do campo. Mas tanto a desconfiança contra os artesãos quanto a idealização dos pequenos proprietários de terra como "a parte mais preciosa do estado" apoiavam-se em sua preocupação com a independência individual como base de liberdade. Os proprietários rurais eram os melhores trabalhadores porque eram "os mais vigorosos, os mais independentes, os mais virtuosos ...". Os artesãos, por outro lado, dependiam das "vicissitudes e caprichos dos fregueses". Se o emprego fosse escasso, não tinham terra a que recorrer para seu sustento. Em sua dependência estava o perigo. "A dependência", argumentava Jefferson, "gera a subserviência e a venalidade, sufoca o germe da virtude e prepara instrumentos adequados para os desígnios da ambição". O fato de os artesãos poderem reivindicar a liberdade sem a independência que a acompanha fazia deles "os instrumentos com os quais as liberdades de um país são geralmente subvertidas” (8).

Na desconfiança de Jefferson contra os artesãos começamos a vislumbrar os limites - e limites não impostos pelo racismo - que definiram a visão republicana do século XVIII. Pois Jefferson não era de modo algum o único entre os republicanos a desconfiar dos trabalhadores sem terra. Essa desconfiança era um corolário da insistência muito difundida no século XVIII sobre o indivíduo independente e proprietário como baluarte da liberdade, insistência que tem sua origem na filosofia política republicana de James Harrington, constituindo um princípio diretivo da política colonial americana, tanto nas assembléias aristocráticas da Carolina do Sul como nas cidades democráticas da Nova Inglaterra (9). Os americanos antes e depois de 1776 aprenderam suas lições republicanas dos teóricos ingleses do commonwealth dos séculos XVII e XVIII; e esses teóricos eram explícitos em seu desprezo pelas massas destituídas da independência dos proprietários que se exigia dos republicanos.

John Locke, autor da clássica explicação do direito à revolução para a proteção da liberdade, não cogitou de estender esse direito aos pobres sem terra. Ao contrário, imaginou para eles e seus filhos um esquema de trabalho forçado. As crianças deveriam começar aos três anos de idade em instituições públicas, chamadas escolas de trabalho porque a única matéria ali ensinada seria o trabalho (fiação e tricô). Seriam pagas com pão e água e 
cresceriam "habituadas a trabalhar". Enquanto isso, as mães, liberadas do cuidado dos filhos, poderiam ir trabalhar com seus pais e maridos. Se não conseguissem um emprego regular, então poderiam também ser enviadas à escola de trabalho (10).

Requer-se certa acuidade mental para distinguir com precisão esta versão de liberação das mulheres do cuidado dos filhos da escravidão pura e simples. E muitos dos sucessores intelectuais de Locke, embora em teoria denunciassem a escravidão, abertamente a preferiram à liberdade para as classes mais baixas de trabalhadores. Adam Ferguson, cujas obras foram muito lidas na América, atribuía a derrubada da república romana, pelo menos em parte, à emancipação dos escravos, que "aumentaram, com seus números e vícios, o peso daquela escória que, em cidades grandes e prósperas, sempre se deposita, dada a sua tendência ao vício e à desordem, até atingir a condição mais baixa" (11).

Entre os republicanos de século XVIII um indiscutível artigo de fé dizia que gente que se encontra na condição mais baixa, a escória da sociedade, geralmente atinge essa posição pelo próprio vício e mau comportamento, quer se trate da antiga Roma ou da moderna Inglaterra. E o vício que se acreditava afligir mais severamente as classes mais baixas era a ociosidade. A cura preferida para a ociosidade daquele século estava contida nas doutrinas éticas e religiosas que R. H. Tawney descreveu como o "Novo Remédio para a Pobreza", doutrinas em que Max Weber discerniu as origens do espírito do capitalismo. Mas em cada sociedade uma massa renitente de homens e mulheres recusava o remédio. Para essas pessoas os teóricos do commonwealth não hesitaram em prescrever a escravidão. Assim Francis Hutcheson, capaz de argumentar com eloqüência contra a escravização de africanos, também argumentava que a escravidão perpétua deveria ser "a punição ordinária daqueles vagabundos ociosos que, depois de advertências adequadas e experiências de servidão temporária, não conseguiam assumir ocupações úteis para sustentar-se a si mesmos e a suas famílias" (12). James Burgh, cuja obra Political Disquisitions lhe valeu elogios de muitos revolucionários americanos, propôs um destacamento de recrutadores "para prender todas as pessoas ociosas e desordeiras que sofreram três queixas perante um magistrado e para fazê-las trabalhar durante um certo tempo, em prol do comércio atacadista ou de empresas manufatureiras etc" (13).

A proposta mais abrangente partiu de Andrew Fletcher de Saltoun. Jefferson saudou em Fletcher um patriota cujos princípios políticos eram "os que estavam em vigor à época da emigração americana [da Inglaterra]. Nossos ancestrais os trouxeram para cá, e eles precisaram de pouco reforço para fazer de nós o que somos ..." (14). Fletcher, como outros teóricos do 
commonwealth, foi um paladino da liberdade, mas também um paladino da escravidão. Atacou a igreja cristã não apenas por ter promovido a abolição da escravidão nos tempos antigos, mas também por ter perpetuado a ociosidade dos libertos que assim se espalharam pela sociedade. A igreja criando hospitais e casas de caridade permitiu que cidadãos através dos séculos vivessem sem trabalhar. Como resultado disso, argumentava Fletcher, sua terra natal, a Escócia, estava sobrecarregada com 200 mil vagabundos ociosos, que vagavam pelo país bebendo, blasfemando, brigando, roubando e matando. Como remédio ele propôs que todos fossem transformados em escravos de cidadãos de posses. À objeção de que seus senhores poderiam abusar deles, respondeu com palavras que poderiam ter sido pronunciadas um século e meio mais tarde por um George Fitzhugh, afirmando que isso iria contra o próprio interesse do senhor, "Que o homem mais cruel não maltrata seu animal apenas por capricho; e que se tal inconveniência às vezes de fato ocorre, ela procede, na maioria das vezes, da perversidade do servo" (15).

Apesar do tributo de Jefferson a Fletcher, não há razão para supor que endossasse sua proposta. Mas ele compartilhava a desconfiança de Fletcher acerca de homens que eram nominalmente livres embora sua barriga vazia fizesse deles ladrões, ameaçando a propriedade de cidadãos honestos, ou então os tornava de fato escravos de qualquer um que os alimentasse. A solução pessoal de Jefferson para o tipo de situação descrito por Fletcher foi apresentada numa famosa carta a Madison, motivada pelo espetáculo por ele encontrado na década de 1780 na França, onde um punhado de nobres monopolizava enormes extensões de terra em que pudessem praticar a caça, enquanto hordas de pobres vagavam sem trabalho e sem pão. A proposta de Jefferson, tipicamente em termos de direito natural, era de que os pobres se apropriassem das terras incultas da nobreza. E ele tirou para os Estados Unidos sua costumeira lição sobre a necessidade de manter a terra amplamente distribuída entre o povo (16).

A resposta de Madison, menos famosa que a carta de Jefferson, levantou a questão da possibilidade de se eliminar os pobres ociosos em qualquer país tão densamente povoado como a França. Espalhados por toda a região seguindo os bons preceitos republicanos, ainda haverá, julgava Madison, "um grande número de habitantes excedentes, superando em muito os que serão empregados para vestir-se a si mesmos e aos que os alimentam ...". Apesar dos que se ocupam no comércio ou como marinheiros, soldados, e assim por diante, restará uma massa de homens sem trabalho. "Um certo grau de miséria", concluiu Madison, "parece inseparável de um alto índice populacional" (17). Ele porém não avançou até propor, como fizera Fletcher, que os miseráveis e os pobres ociosos fossem escravizados. 
A situação contemplada por Madison e confrontada por Fletcher não era irrelevante para os que estavam planejando o futuro da república americana. Num país em que a população crescia numa proporção geométrica não era cedo demais para pensar numa época em que possivelmente houvesse inúmeros pobres sem terra, quando talvez houvesse nas grandes cidades aquelas multidões que Jefferson temia como feridas no corpo político. Nos Estados Unidos que Jefferson e Madison conheceram a mão-de-obra urbana ainda não constituía um problema por ser diminuta, e a mão-de-obra agrícola já era, em grande maioria, escravizada. Na América revolucionária, dentre os homens que passavam a vida trabalhando para outros em vez de trabalhar para si mesmos, os escravos provavelmente constituíam a maior parte (18). Na Virgínia eram a grande marioria (19). Se Jefferson e Madison, sem mencionar Washington, sentiam mal-estar perante esse fato e mesmo assim nada fizeram para mudá-lo, talvez tenham sido impedidos, pelo menos em parte, por considerações sobre o papel que poderia desempenhar nos Estados Unidos uma grande massa de trabalhadores livres (20).

Quando Jefferson contemplou a abolição da escravidão, julgou inconcebível permitir que os libertos permanecessem no país. Esta atitude foi provavelmente motivada por um preconceito racial seu ou de seus compatriotas. Mas ele também pode ter pensado na possibilidade de que, libertos, em vez de escravos eles se tornariam meio milhão de pobres ociosos, criando para os Estados Unidos os mesmos problemas que os pobres ociosos da Europa criavam para seus Estados. O escravo, acostumado ao trabalho compulsório, não trabalharia para o próprio sustento quando a compulsão fosse removida. Essa forma de pensar era lugar-comum entre os senhores de plantations da Virgínia antes da criação da república e durante muito tempo depois. "Se você libertar os escravos", escreveu London Carter dois dias após a Declaração da Independência, "deve mandá-los para fora do país ou então eles precisarão roubar para sustentar-se” (21).

O plano de Jefferson de libertar seus próprios escravos (nunca posto em prática) incluía um período educativo intermediário durante o qual eles em parte aprenderiam a sustentar-se a si mesmos trabalhando em terra arrendada e em parte seriam obrigados a fazê-lo, uma vez que, na sua opinião, sem orientação e preparação para o auto-sustento não se poderia esperar que os escravos se tornassem membros adequados de uma sociedade republicana" (22). E St. George Tucker, que esboçou planos detalhados para libertar os escravos da Virgínia, preocupava-se com “a possibilidade de que eles se tornassem ociosos, libertinos e finalmente bandidos, em vez de aplicar-se ao trabalho". Por isso incluiu em seu plano uma cláusula que tornava obrigatório o trabalho dos libertos numa base anual. "Não pode- 
mos ignorar esta importante consideração", dizia ele, "que essa gente precisa ser obrigada a trabalhar, se não se comprometer voluntariamente a fazêlo ... Quando os libertamos do jugo da escravidão, não devemos esquecer os interesses da sociedade. Tais interesses exigem os esforços de todos os indivíduos de um modo ou de outro. E aqueles que não têm como se sustentar honestamente sem trabalho braçal, seja qual for a cor de sua pele, devem ser obrigados a trabalhar" (23).

Está claro que Tucker, o futuro emancipador, desconfiava dos pobres ociosos independentemente da cor. E parece provável que os paladinos revolucionários da liberdade, que aceitavam a continuação do trabalho escravo dos negros, assim agiam não apenas por preconceito racial mas também por compartilharem com Tucker a desconfiança contra os pobres que era inerente às concepções de liberdade republicana do século XVIII. Seus guias históricos lhes fizeram temer a ampliação da mão-de-obra livre.

Aquele temor, creio eu, tinha um segundo ponto de origem na experiência dos colonizadores americanos, e especialmente dos virginianos, no século e meio anterior. Se voltarmos agora para a história precedente da mão-de-obra da Virgínia, poderemos encontrar, penso eu, alguns outros indícios da desconfiança contra o trabalho livre entre os revolucionários republicanos e do paradoxal surgimento da escravidão juntamente com o ideal de liberdade na América do período colonial.

A história começa propriamente na Inglaterra com a explosão do crescimento populacional que fez o número de ingleses subir de talvez três milhões em 1500 para quatro milhões e meio em 1650 (24). O crescimento não se deu em resposta a um aumento correspondente da capacidade da economia da ilha para sustentar seu povo. E o resultado foi precisamente a miséria mostrada a Jefferson por Madison como conseqüência de "um alto índice populacional”. A Inglaterra do século XVI conheceu o mesmo tipo de desemprego e pobreza que Jefferson testemunhou na França do século XVIII e Fletcher na Escócia do século XVII. Números alarmantes de ociosos e famintos vagavam pelo país em busca de oportunidades de trabalho ou de saque. O governo fazia o possível para que homens de fortuna os empregassem, mas também adotava medidas cada vez mais severas contra suas andanças, seus furtos, suas desordens e, na verdade, contra sua existência. Aqueles que as casas de trabalho e prisões não conseguiam engolir, a forca teria de eliminar ou talvez o exército. Quando a Inglaterra precisava realizar expedições no exterior, cada freguesia despachava seus habitantes mais indesejados para a morte quase certa que encontrariam em doenças ou no campo de batalha (25). 


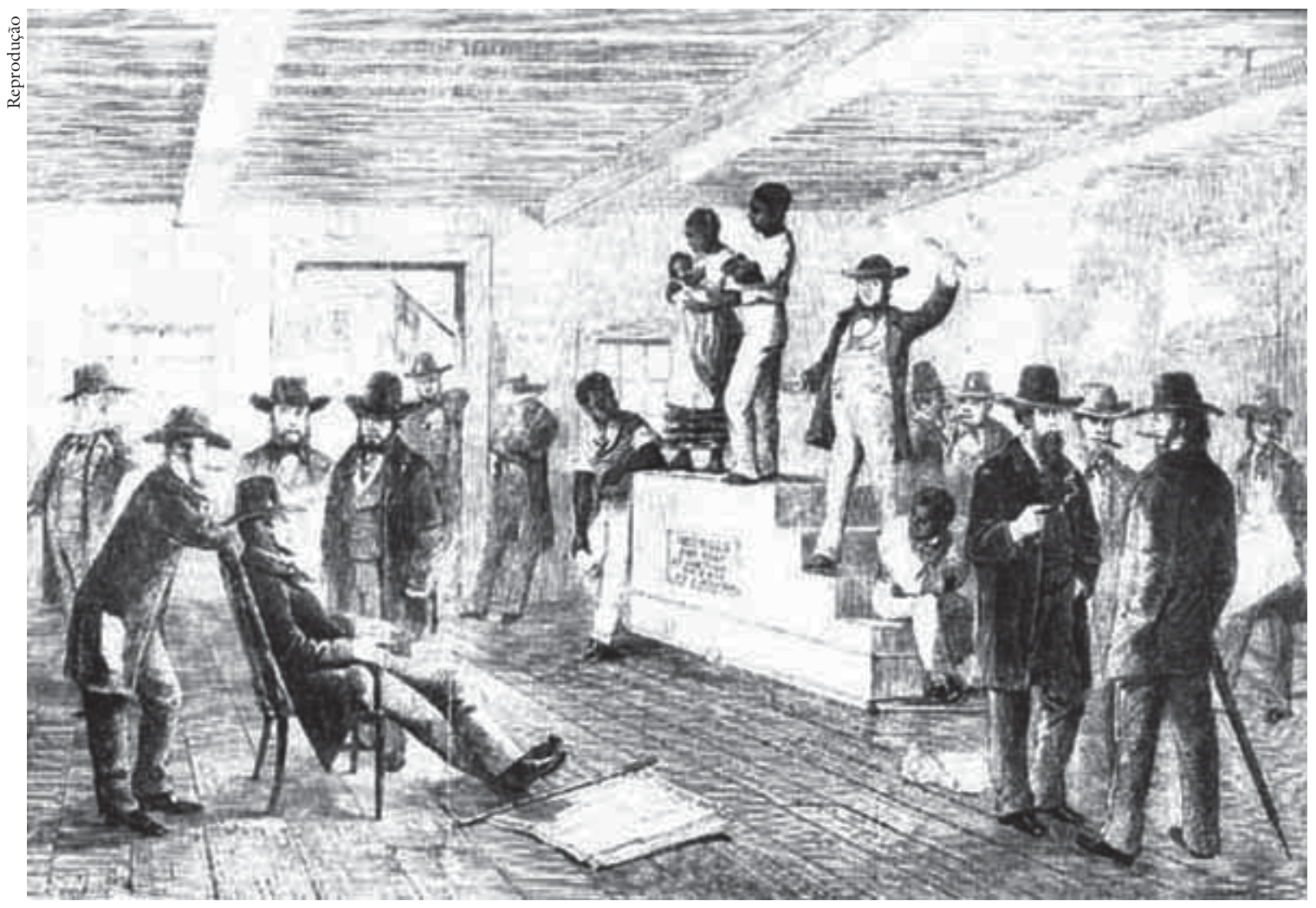

Ilustração retratando leilão de escravos no Sul dos Estados Unidos

À medida que a massa de malandros e mendigos crescia e cada vez mais ameaçava a paz da Inglaterra, os esforços para lidar com eles sempre mais ameaçavam as liberdades no país. Os ingleses se orgulhavam de seu gentle government (26), um governo que havia libertado seus súditos das velhas formas de sujeição e lhes concedera novas liberdades, fazendo que a frase "direito dos ingleses" tivesse poderes mágicos. Mas não havia nada de gentil no tratamento que o governo dispensava aos pobres; e à medida que mais ingleses empobreciam, outros ingleses tinham menos motivos para se orgulhar. As cabeças pensantes descobriram uma nova solução: mandar os ingleses excedentes para fora da Inglaterra. Enviá-los para o Novo Mundo, onde as oportunidades de trabalho eram ilimitadas. Lá eles se redimiriam a si mesmos, enriqueceriam a pátria-mãe e espalhariam a liberdade inglesa no exterior.

O maior propagandista desse programa foi Richard Hakluyt. Seu livro Principal Navigations, Voiages and Discoveries of the English Nation (27) não continha simplesmente a narrativa das viagens dos ingleses pelo mundo mas também uma poderosa sugestão de que o mundo deveria ser inglês ou, no mínimo, dirigido por ingleses. Hakluyt sonhava com um império bene- 
volente, em que a Inglaterra conferiria as bênçãos de seu próprio governo livre aos povos menos afortunados do mundo. É sem dúvida verdade que os ingleses, juntamente com outros europeus, já estavam imbuídos de preconceitos contra povos de pele mais escura que a deles. E é também verdade que os principais beneficiários do império de Hakluyt seriam os ingleses. Mas o seu sonho não pode ser descartado como simples hipocrisia assim como não podemos descartar a afirmação da igualdade dos homens feita por Jefferson. A compaixão de Hakluyt pelos pobres e oprimidos não se restringia aos pobres da Inglaterra, e nas explorações de Francis Drake pelo Caribe, Hakluyt viu não uma mal disfarçada forma de pirataria, mas um modelo de libertação de homens de todas as cores que penavam sob a tirania dos espanhóis.

Drake desembarcara no Panamá em 1572 e travara amizade com um bando extraordinário de escravos negros fugitivos. "Cimarrons" é como se denominavam, e levavam uma vida livre e dura numa região inculta, fazendo incursões periódicas pelos assentamentos espanhóis para levar consigo mais membros de seu povo. Em Drake descobriam um homem que odiava os espanhóis tanto quanto eles e que tinha armas e homens para organizar um ataque mais forte do que eles poderiam fazer isoladamente. Drake queria o ouro dos espanhóis, e os Cimarrons queriam o ferro para fazer ferramentas. Ambos queriam que os espanhóis morressem. A aliança foi espontânea e aparentemente nada atrapalhada pelo preconceito racial. Numa ação conjunta assaltaram a caravana de mulas que transportava pelo istmo a carga anual de ouro peruano. E antes de zarpar para a Inglaterra com seu saque, Drake combinou futuros encontros (28). Quando ouviu falar dessa aliança, Hakluyt concebeu sua primeira proposta de colonização: um esquema para tomar o Estreito de Magalhães e para lá transportar os Cimarrons juntamente com excedentes ingleses. $\mathrm{O}$ estreito seria um ponto estratégico forte para o império mundial da Inglaterra, uma vez que podia controlar a rota do Atlântico ao Pacífico. Apesar do rigor do clima do lugar, os Cimarrons e seus amigos ingleses viveriam calorosamente todos juntos, vestindo roupas de lã inglesa, "bem alojados e por nossa nação libertados dos tirânicos espanhóis, e serena e cortesmente governados por nossa nação" (29).

O esquema para uma colônia no Estreito de Magalhães nunca deu certo, mas perdurou a visão de Hakluyt, de libertos nativos e excedentes ingleses cortesmente governados em colônias inglesas espalhadas pelo mundo. Sir Walter Raleigh entendeu a visão. Sonhava em arrebatar o tesouro dos Incas das mãos dos espanhóis mediante uma aliança com os índios da Guiana e, enviando ingleses para conviver com eles, conduzi-los em sua rebelião contra a Espanha e governá-los à maneira inglesa (30). Raleigh também sonhava com uma colônia semelhante no país que chamou de 
Virgínia. Hakluyt ajudou-o a planejá-la (31). E Drake ficou de prontidão para fomentar o empreendimento fornecendo negros e índios, libertados da tirania espanhola no Caribe (32).

A Virgínia foi desde o início concebida não apenas como um refúgio para os pobres sofridos da Inglaterra, mas também como uma ponta de lança da liberdade inglesa num mundo oprimido. Tal era o sonho. Mas quando começou a concretizar-se em Roanoke Island em 1585, algo deu errado. Drake fez sua parte libertando escravos espanhóis no Caribe e levando para Roanoke aqueles que quisessem se juntar a ele (33). Mas os ingleses enviados por Raleigh não se mostraram dignos do papel que lhes foi atribuído. Aguardando que Drake chegasse não se mostraram nada corteses com os índios de cuja assistência dependiam. Os colonos do primeiro grupo assassinaram o chefe que os recebera como amigos, e depois desistiram e correram de volta para casa a bordo dos navios de Drake. Os do segundo grupo simplesmente desapareceram, presume-se que mortos pelos índios (34).

$\mathrm{O}$ que se perdeu nessa famosa colônia perdida foi mais do que um bando de colonizadores de que nunca mais se teve notícia. O que também se perdeu e nunca mais se recuperou totalmente em aventuras posteriores foi o sonho de ingleses e índios vivendo lado a lado em paz e liberdade. Quando os ingleses finalmente instalaram uma colônia permanente em Jamestown vieram como conquistadores, e seu governo não foi nada gentil. Os índios predispostos a submeter-se a ele eram pouquíssimos e estavam espiritualmente por demais abatidos para desempenhar um papel significativo na colônia.

Sem essa ajuda, a Virgínia oferecia uma triste alternativa da casa de trabalho ou da forca aos primeiros ingleses pobres para lá transportados. Durante as primeiras duas décadas da colônia, a maioria dos imigrantes encontraram muito pouca liberdade inglesa na Virgínia (35). Na década de 1630 a colônia parecia estar funcionando, pelo menos em parte, segundo as expectativas dos primeiros senhores de plantations. Ingleses empobrecidos chegavam anualmente em grande escala, comprometidos a servir aos senhores da região por um determinado número de anos, com a perspectiva de estabelecer a própria casa alguns anos mais tarde. Os colonizadores estavam se espalhando ao longo dos grandes rios da Virgínia, formando plantations, vivendo confortavelmente do cultivo do milho e do gado criado solto na floresta, e ganhando ao mesmo tempo de $£ 10$ a 12 por pessoa com a produção de tabaco. Uma assembléia legislativa representativa garantia as liberdades tradicionais dos ingleses e permitia a participação no seu próprio governo de uma parcela da população maior do que jamais fora na 
Inglaterra. A colônia até começou a parecer-se um pouco com o refúgio cosmopolita de liberdade que Hakluyt inicialmente imaginara. Homens de todos os países apareciam por lá: franceses, espanhóis, holandeses, turcos, portugueses e africanos (36). A Virgínia os acolhia e começava a transformálos em ingleses.

Parece claro que a maioria dos africanos, talvez todos eles, vieram como escravos, condição que se tornara obsoleta na Inglaterra, embora estivesse se tornando a condição esperada dos africanos fora da África e de muitos no seio do próprio continente (37). Todos, servos, escravos ou livres, gozavam quase dos mesmo direitos e deveres dos outros virginianos. Não há provas durante o período anterior a 1660 de que fossem submetidos a uma disciplina mais severa em relação a outros servos. Podiam processar e sofrer processos no tribunal. Cumpriam penitência na igreja da freguesia por ter filhos ilegítimos. Ganhavam seu próprio dinheiro, compravam e vendiam e criavam seu gado. Às vezes compravam a própria liberdade. Em outros casos, seus senhores legavam-lhes não apenas a liberdade mas também terra, gado e casas (38). Northampton, único condado sobre o qual dispomos de registros completos, tinha pelo menos dez famílias negras livres em 1668 (39).

À medida que os negros foram tomando seu lugar na comunidade, foram aprendendo as maneiras inglesas, incluindo-se até a truculência com a autoridade sempre associada aos direitos dos ingleses. Tony Longo, um negro livre de Northampton, quando intimado por ordem judicial a comparecer como testemunha perante o tribunal, respondeu com uma opinião escatológica sobre ordens judiciais, chamou o homem que lhe apresentava a intimação de velhaco desocupado e o mandou cuidar de sua vida. O homem ofereceu-se para comparecer com ele perante um juiz de paz a qualquer hora de modo que suas provas pudessem ser registradas. Iria com ele à noite, no dia seguinte, na semana seguinte, quando ele quisesse. Mas Longo estava ocupado com a colheita do milho. Rejeitou todas as súplicas com um "Tá bom, tá bom. Vou depois de colher o milho", e recusou-se a receber a intimação (40).

É compreensível que os juízes tenham interpretado o acontecido como desacato à autoridade. Mas era o tipo de desacato que os ingleses livres muitas vezes mostravam, e estava associado a uma devoção ao trabalho que os moralistas ingleses tudo faziam para inculcar o mais amplamente possível na Inglaterra. Como a Inglaterra absorvera pessoas de todas as nacionalidades ao longo dos séculos e os transformara em ingleses, os ingleses da Virgínia estavam absorvendo sua quota de estrangeiros, incluindo-se negros, e pareciam estar moldando com êxito no Novo Mundo uma comunidade baseada no modelo inglês. 
Mas um olhar mais atento mostrará que a situação não era exatamente tão promissora quanto à primeira vista parecia. Sabe-se muito bem que a Virgínia em seus primeiros 15 ou 20 anos matou a maioria dos homens que lá chegaram. Se minha estimativa do fluxo de imigração se aproxima do correto, a Virgínia deve ter sido uma armadilha mortal durante o período de, no mínimo, outros 15 anos e é provável que esse período tenha se estendido por 20 ou 25 anos. Em 1625 a população estabilizou-se em 1.300 ou 1.400; em 1640 era de cerca de 8 mil (41). Nos 15 anos entre essas duas datas pelo menos 15 mil pessoas devem ter chegado à colônia (42). Neste caso, 15 mil imigrantes aumentaram a população em menos de 7 mil pessoas. Não temos provas de um grande refluxo migratório. Parece provável que a taxa de morte durante esse período só foi comparável ao verificado na Europa durante os anos de pico de um surto de peste. A Virgínia, em outras palavras, estava absorvendo os trabalhadores ingleses excedentes sobretudo para matá-los. O sucesso dos que sobreviveram e evoluíram de servos a senhores de plantations deve ser em parte atribuído ao fato de que tão poucos sobreviveram.

Depois de 1640, quando as doenças responsáveis pela elevada taxa de mortalidade declinaram e a população começou a crescer rapidamente, tornou-se cada vez mais difícil para um imigrante indigente vencer na vida. A população provavelmente superava os 25 mil em 1662 (43), longe do que Madison chamaria de alto índice populacional. Todavia, o rápido crescimento trouxe sérios problemas para a Virgínia, entre eles a monopolização de terras junto à foz dos rios com apropriação de milhares e dezenas de milhares de acres feita por especuladores que perceberam a alta da demanda (44).

O fato provocou enorme expansão da produção de tabaco, o que ajudou a derrubar o preço do produto e os lucros dos produtores (45). Provocou também esforços dos produtores para prolongar os contratos dos empregados, uma vez que agora era maior a longevidade e portanto a expectativa de serventia (46).

Seria, de fato, difícil avaliar as conseqüências do aumento da longevidade. Mas para os nossos propósitos uma evolução foi crucial: o aparecimento na Virgínia de um número crescente de homens livres que haviam cumprido seu contrato, mas não reuniam condições para comprar sua própria terra a não ser nas fronteiras ou no interior. Nos anos em que os preços do tabaco eram particularmente baixos, ou as safras muito ruins, cidadãos que apenas ganhavam para sobreviver eram obrigados a voltar a trabalhar para seus vizinhos economicamente mais fortes apenas para não morrer de fome. Por volta de 1676 estimava-se que um quarto dos homens livres da Virgínia não eram proprietários de terra (47). No mesmo ano Francis 
Moryson, membro do conselho do governador, explicava que o termo freedmen [libertos] usado na Virgínia denotava "pessoas sem casa ou terra", significando ser essa agora a condição normal dos servos que haviam conseguido a liberdade (48).

Alguns deles resignavam-se a trabalhar por salário. Outros preferiam viver na pobreza na perigosa zona da fronteira ou levar uma vida precária, vagando de um condado a outro, alugando um pedaço de terra aqui, ocupando outro ali, fugindo do coletor de impostos, bebendo, brigando, roubando suínos e aliciando servos a ir embora com eles.

A presença dessa classe cada vez maior de virginianos caídos na pobreza não assustava pouco os senhores de plantations que haviam conseguido chegar ao topo ou que já estavam no topo quando vieram para a colônia bem providos de servos e capital. Estavam presos num dilema. Queriam os imigrantes que continuavam a jorrar todos os anos. De fato precisavam deles e os apreciavam mais à medida que viviam mais. Todavia, sendo que eles em número cada vez maior se tornavam livres a cada ano, a colônia parecia ter herdado o problema que estava ajudando a Inglaterra a solucionar. A Virgínia, queixava-se Nicholas Spencer, secretário da colônia, era um "ralo para drenar a Inglaterra de sua sujeira e escória (49).

Os homens que preocupavam a camada mais alta pareciam ainda mais perigosos na Virgínia do que tinham sido na Inglaterra. Eram, para começar, jovens, porque eram os jovens que os senhores das plantations queriam para o trabalho no campo. E os jovens, quando não abertamente rebeldes, sempre pareceram ter pouca paciência com o controle exercido pelos mais velhos e superiores. Também predominavam entre eles os solteiros, pelo fato de os donos de terras não acharem que as mulheres, pelo menos não as inglesas, servissem para trabalhar no campo. Entre os imigrantes, os homens superavam as mulheres na proporção de três ou quatro para uma, ao longo de todo o século (50). Conseqüentemente, a maioria dos libertos não tinha mulher ou família para domar seus impulsos mais fortes e fazer deles reféns de um mundo respeitável.

Por fim, o que tornava esses jovens indômitos particularmente perigosos era o fato de que estavam armados e precisavam andar armados. A vida na Virgínia exigia armas de fogo. As plantations estavam sujeitas a ataques terrestres de índios e marítimos de corsários e pequenos piratas (51). Sempre que a Inglaterra estava em guerra com franceses ou holandeses, os colonos precisavam estar preparados para defender-se. Em 1667 os holandeses numa única incursão capturaram 20 navios comerciantes no rio James, juntamente com o navio de guerra inglês que supostamente deveria defendê- 
los; em 1673 capturaram mais 11. Em ocasiões como essas o governador William Berkeley reunia os colonos em pé de guerra e pelo menos impedia que o inimigo fizesse um desembarque. Mas enquanto ele rechaçava os holandeses, preocupava-se com a rude multidão às suas costas. Dentre os homens fisicamente aptos da colônia ele estimava que "pelo menos um terço são libertos solteiros (cujo trabalho mal pode sustentá-los) ou homens muito endividados, duas categorias que, podemos esperar, diante de qualquer pequena vantagem que o inimigo possa vir a ter sobre nós, se revoltariam a favor dele na esperança de melhorar suas condições dividindo com ele o produto do saque da região" (52).

Os temores de Berkeley eram justificados. Três anos depois, detonada não por uma invasão holandesa mas por um ataque de índios, a rebelião alastrou-se pela Virgínia. Começou, quase como fora previsto por Berkeley, quando um grupo voluntário de combatentes dos índios, depois de um ataque infrutífero contra os nativos, voltou-se contra seus próprios dirigentes. Essa Rebelião de Bacon foi a maior insurreição popular nas colônias antes da Revolução Americana. Mais cedo ou mais tarde todos os habitantes da Virgínia se envolveram, mas ela começou nos condados da fronteira de Henrico e New Kent, entre homens que o governador e seus amigos sempre classificaram como ralé (53). À medida que a rebelião se expandia para o Leste, constatou-se que havia ralé em toda parte, e Berkely, com razão, elevou a estimativa de seus integrantes. "Como é infeliz o homem", exclamava, "que governa um povo do qual pelo menos seis partes dentre sete são pobres, endividados, descontentes e armados” (54).

Os pobres da Virgínia tinham uma razão para sentirem inveja e raiva dos proprietários de terra que importavam servos e governavam. Mas a rebelião não produziu qualquer programa de reformas, nenhuma ideologia, nem mesmo qualquer slogan revolucionário. Buscava-se o saque e não princípios. E quando os rebeldes haviam redistribuído toda a riqueza em que conseguiram pôr as mãos, a rebelião cedeu quase com a mesma rapidez com que se alastrara.

Foi, porém, uma experiência devastadora para as primeiras famílias da Virgínia. Elas se viram mutuamente aderindo aos rebeldes no intuito de salvar a própria pele ou suas posses ou até sua parte do saque. Quando tudo terminou, todos ficavam de olho um no outro desconfiados, à espreita de qualquer novo Bacon entre eles, que pudesse ser tentado a conduzir a ainda indócil ralé a outras expedições e saques. Quando William Byrd e Laurence Smith propuseram resolver os problemas da defesa contra os índios mediante a criação de assentamentos de contenção semi-independentes nas cabeceiras dos rios, em cada um dos quais eles se comprometiam a manter 50 
homens armados, a assembléia a princípio reagiu de modo favorável. Mas logo ocorreu ao governador e ao seu conselho que a medida de fato significava reunir uma multidão de desenfreados solteirões da Virgínia e fornecer-lhes armas e munição em abundância. O próprio Byrd conduzira uma multidão semelhante numa incursão de saques durante a rebelião. Encarregálo a ele ou a qualquer outro de conduzir uma gangue de homens armados era pedir-lhes que novamente atacassem o povo que supostamente deveriam proteger (55).

O nervosismo dos donos de propriedades que valessem a pena saquear continuou ao longo de todo o século, acirrado em 1682 pelos tumultos que promoveram o corte do tabaco, durante os quais homens percorriam os campos destruindo as plantações, na desesperada esperança de provocar a escassez que elevaria os preços da folha de tabaco (56). E de tempos em tempos, nas colônias vizinhas de Maryland e Carolina do Norte, onde a situação era a mesma da Virgínia, havia tumultos que ameaçavam se espalhar até esta última (57).

Assim como a Virgínia criara um problema social análogo ao da Inglaterra, da mesma forma a colônia começou a lidar com ele como o fizera a pátria-mãe, restringindo a liberdade dos que não tinham a apropriada insígnia dos livres, isto é, a propriedade que o governo deveria proteger. Uma das formas para tanto consistiu em ampliar os termos de serviço dos servos que chegavam à colônia sem contratos. Antes, eles serviam até os 21 anos; agora a idade se estendera até os 24 (58). Sempre houvera leis exigindo deles tempos adicionais de serviço por fugas; agora as leis acrescentaram punições físicas e, no intuito de tornar reconhecíveis os transgressores contumazes, especificou-se que seu cabelo deveria ser raspado (59).

Novas leis restringiram a circulação de servos por estradas e também aumentaram o tempo adicional de serviço por fuga. Além de servir dois dias para cada dia de ausência, exigia-se agora que o fugitivo capturado compensasse com trabalho a perda da colheita que ele deixara de fazer e pelas custas de sua captura, incluindo-se o prêmio pago por ela (60). Férias de três semanas poderiam resultar em um ano a mais de serviço (61). Se um servo atacasse seu senhor, tinha de servir mais um ano (62). Por matar um porco serviria por um ano ao dono e por outro ao informante, sendo que o dono do porco, o dono do servo e o informante freqüentemente eram a mesma pessoa. Considerando-se que o porco valia no máximo menos de um décimo do salário anual de um servo, a lei era muito lucrativa para a classe dos senhores. Um senhor de Lancaster recebeu a recompensa de seis anos de trabalho adicional de um servo que matou três porcos, cujo valor era de aproximadamente trinta xelins (63). 
O efeito dessas medidas foi impedir, pelo tempo mais longo possível, que os servos conseguissem a liberdade, especialmente aquele tipo de servos com maior propensão a causar problemas. Ao mesmo tempo, a monopolização de terras estava empurrando a muitos de volta para a servidão depois de uma breve passagem pela liberdade. Os libertos que assumiam trabalho por salário voltavam assim à servidão, sujeitos praticamente às mesmas restrições dos outros servos.

Contudo, apesar de todas as pressões legais e econômicas para manter os cidadãos empregados, as fileiras dos libertos cresciam, assim como a pobreza e o descontentamento. Para impedir que solteirões insubordinados conseguissem influir no governo, em 1670 a assembléia restringiu o direito de voto aos donos de terras e chefes de família (64). Mas privar de direitos civis a massa crescente de solteiros livres não significava privá-los das armas que eles, com tanta eficiência, haviam empunhado sob as ordens de Nathaniel Bacon. Pode-se questionar até onde a Virgínia poderia ter prosseguido ao longo dessa rota, enfrentando o descontentamento com a repressão e guarnecendo suas plantations com importações anuais de servos que mais tarde se juntariam às fileiras rebeldes dos homens livres. Com certeza, os que estavam na base da pirâmide poderiam ter conseguido terra e liberdade, como aconteceu com os colonos de outras partes, se a fronteira da Virgínia estivesse a salvo dos índios ou se os homens do topo estivessem predispostos a abrir mão de seus lucros e a ceder parte das terras que haviam monopolizado. O próprio governo inglês empenhou-se para dividir os grandes domínios que ajudaram a criar o problema (65). Mas é improvável que os dirigentes políticos de Whitehall estivessem dispostos e brigar por muito tempo contra os bem-sucedidos.

De qualquer modo não foi preciso. Houve outra solução, que permitiu aos magnatas da Virgínia manterem suas terras, evitando o descontentamento e repressão de outros ingleses, uma solução que reforçou os direitos desses cidadãos e alimentou aquele apego à liberdade que passou a ser desfrutado pela geração revolucionária de estadistas da Virgínia. A solução porém pôs termo ao processo de transformar africanos em ingleses. Os direitos dos ingleses foram preservados mediante a destruição dos direitos dos africanos.

Não quero argumentar que os virginianos recorreram deliberadamente à escravidão africana como um dos meios de preservar e estender os direitos dos ingleses. Winthrop Jordan sugeriu que a escravidão veio para a Virgínia como uma decisão impensada (66). Podemos ir além e dizer que veio sem decisão alguma. Veio automaticamente à medida que os virginianos compraram a mão-de-obra mais barata que encontraram. Assim que se reduziu o alto índice de mortalidade na Virgínia, um investimento em mão-de-obra escrava 
era mais lucrativo do que um investimento em mão-de-obra livre; e os senhores das plantations compravam escravos com a mesma rapidez com que os mercadores os disponibilizavam. Nos últimos anos do século XVII foram comprados em tão grande quantidade que em 1700 eles provavelmente já constituíam a maior parte ou quase toda a mão-de-obra existente (67). A demanda era tão grande que os traficantes durante algum tempo tinham na Virgínia um mercado melhor que na Jamaica ou em Barbados (68). Mas os benefícios sociais da mão-de-obra escrava, embora não fossem conscientemente procurados ou reconhecidos peles compradores de escravos, foram maiores que os benefícios econômicos. O aumento da importação de escravos correspondeu à redução da importação de servos contratados e, conseqüentemente, à redução do perigoso número de novos libertos que anualmente emergiam procurando na sociedade um lugar que não conseguiriam encontrar (69).

Se não houvesse africanos disponíveis, provavelmente teria sido impossível achar uma forma de manter, em seu lugar, o contínuo fornecimento de imigrantes ingleses. Havia um limite além do qual a redução das liberdades inglesas teria resultado não apenas em rebelião mas em protestos da Inglaterra e no corte do suprimento de outros servos. Na época da rebelião de Francis Bacon a comissão de investigação inglesa havia mostrado mais simpatia pelos rebeldes do que pelos colonos bem-sucedidos que monopolizaram as terras da Virgínia. Tentar a escravização de trabalhadores ingleses em vez de restaurar a ordem teria causado mais desordem. Mas manter como escravos os negros que vieram como escravos era possível e aparentemente considerado bom senso.

A atitude das autoridades inglesas foi claramente expressa pelo procurador que revisou para o Privy Council (Conselho Particular do trono) as leis dos escravos estabelecidas em Barbados em 1679. Julgou que eram leis bem concebidas para o bem dos súditos locais de sua majestade. Segundo ele, "embora os negros naquela ilha possam ser punidos de modo diferente e mais severo do que ocorre com outros súditos por ofensas da mesma natureza, contudo, humildemente entendo que as leis de lá referentes aos negros são razoáveis pois, devido a seu número, eles se tornam perigosos, e sendo uma espécie de povo selvagem e naquela ilha considerado como mercadoria, é necessário ou pelo menos conveniente ter para eles leis diferentes das leis da Inglaterra, a fim de impedir o grande mal que caso contrário poderia acontecer aos senhores de plantations e habitantes daquela ilha" (70).

Na Virgínia também pareceu conveniente e razoável ter leis diferentes para negros e brancos. Como o número de escravos crescia, a assembléia aprovou leis que fizeram avançar com muito mais rigor a tendência já posta em prática em leis trabalhistas da colônia. O rigor porém estava reservado 
para as pessoas que não tinham pele clara. As leis desobrigavam o senhor que acidentalmente castigava seu escravo até a morte, mas estabeleciam novos limites para punições de "servos brancos cristãos" (71).

Os virginianos preocupavam-se com o risco de ter em seu meio um grupo de homens que tinham todos os motivos para odiá-los (72). O medo de uma insurreição de escravos pairou sobre eles por quase dois séculos. Mas o perigo representado pelos escravos na prática mostrou-se menor do que o perigo que a colônia enfrentara representado pelos libertos irrequietos e armados. Os escravos não alimentavam qualquer das expectativas de ascensão que tantas vezes provocam o descontentamento humano. Ninguém lhes havia dito que tinham direitos. Tinham sido criados em sociedades pagãs nas quais haviam perdido a liberdade; seus filhos seriam criados numa sociedade cristã e jamais conheceriam a liberdade.

Além disso, os escravos sentiam menos o problema do desequilíbrio sexual que ajudou a tornar os trabalhadores livres da Virgínia tão irrequietos. Num sistema de mão-de-obra escrava podia-se exigir que as mulheres trabalhassem na produção de tabaco da mesma forma que os homens. E elas também faziam filhos, que em poucos anos seriam um ativo financeiro de seu senhor. Desde o início, portanto, os traficantes importaram mulheres numa proporção muito superior em relação aos homens do que ocorria com os servos ingleses (73), e o nível de descontentamento era proporcionalmente menor. Os virginiamos não tinham dúvidas de que o descontentamento continuaria, mas poderia ser reprimido com métodos que não teriam sido considerados razoáveis, convenientes ou mesmo seguros, se aplicados aos ingleses. Os escravos podiam ser privados de oportunidades de associação e rebelião. Podiam ser mantidos desarmados e desorganizados. Podiam ser submetidos a castigos bárbaros por seus donos sem medo de represálias legais. E sua cor mostrando sua provável condição social, o resto da sociedade poderia mantê-los sob rigoroso controle. Não deve surpreender que nenhuma insurreição de escravos se parecesse, em extensão e êxito, com a Rebelião de Bacon.

Também não pode surpreender o fato de que os libertos da Virgínia nunca mais foram uma ameaça à sociedade. Embora anos mais tarde a escravidão fosse condenada porque se julgou que competisse com a mão-deobra livre, no início ela reduziu muito o número de libertos que em outras circunstâncias teriam competido entre si. Com a redução do incremento anual de libertos, ficou mais fácil para o pequeno número de remanescentes achar um lugar independente na sociedade, especialmente à medida que o perigo de ataques de índios foi diminuindo, o que tornou mais seguros os assentamentos nas cabeceiras dos rios e na fronteira com as Carolinas. Tal- 
vez ainda houvesse alguns libertos irredimíveis, ociosos e rebeldes, sobretudo entre os condenados que a Inglaterra exportava para as colônias. Mas eram poucos, de modo que se podia lidar com eles usando o velho recurso de convocá-los para expedições militares (74). Ficava assim facilitado o acesso à aquisição de propriedade para os outros libertos, que podiam talvez adquirir um ou dois escravos e juntar-se aos seus superiores no gozo daquelas liberdades inglesas que os diferenciava dos trabalhadores negros.

Uma sociedade livre dividida entre grandes e pequenos proprietários de terra era muito menos dilacerada por antagonismos do que uma sociedade dividida entre proprietários de terra e homens sem terra e sem patrão. Tendo recuperado status, sobriedade e expectativas, os libertos já não eram homens a temer. $\mathrm{O}$ fato, juntamente com a presença de uma massa crescente de escravos alienígenas, provocou uma aproximação maior dos colonizadores brancos entre si e reduziu a importância da diferença de classe entre o pequeno agricultor e o grande latifundiário (75).

O século XVII foi algumas vezes considerado como a época do pequeno agricultor na Virgínia. Todavia, sob muitos aspectos, há argumentos muito fortes para considerarmos o século XVIII como a época em que o pequeno agricultor veio a ocupar seu espaço, uma vez que a escravidão o livrara das pressões que o haviam continuamente reduzido à condição de servo. Essa interpretação se conforma com o desenvolvimento político da colônia. Durante o século XVII o conselho do governador, indicado pelo trono inglês e integrado pelos maiores proprietários da colônia, constituíra $\mathrm{o}$ mais poderoso corpo dirigente. Mas à medida que a onda de escravos foi crescendo entre 1680 e 1720 a Virgínia passou a ter um governo em que o pequeno proprietário foi ocupando um espaço maior. Apesar de o surgimento das grandes famílias da Virgínia com a maré negra, o poder do conselho declinou; e a House of Burgesses com seus poderes eletivos tornou-se o órgão dominante do governo. Seus membros alimentavam um relacionamento mais próximo com seu eleitorado de pequenos proprietários, o que não acontecera antes (76). E foi em seus recintos que os virginianos desenvolveram as idéias tão fervorosamente defendidas na Revolução: idéias sobre impostos, representação e direitos dos ingleses, e idéias sobre as prerrogativas, os poderes e a vocação sagrada do pequeno agricultor, proprietário e independente - idéias do commonwealth.

No século XVIII, já sem a ameaça de uma classe trabalhadora livre e perigosa, os virginianos puderam alimentar tais idéias, que na época de Berkeley não fora possível. O próprio Berkeley vivia sob a obsessão das guerras civis inglesas e do perigo da rebelião. Desprezava e temia os cidadãos da Nova Inglaterra por sua associação com os puritanos que transfor- 
maram a Inglaterra, ainda que por um tempo breve, numa república (77). Orgulhava-se de que a Virgínia, ao contrário da Nova Inglaterra, não tinha escolas livres nem imprensa, porque livros e escolas geram heresias e sedição (78). Berkeley deve ter-se comprazido com o fato de que, quando seu povo de fato se rebelou contra ele sob as ordens de Bacon, não se gerou nenhuma idéia republicana, nenhuma filosofia sobre rebelião ou direitos humanos. Mesmo assim, um século mais tarde, sem o benefício de rebeliões, os virginianos haviam aprendido lições republicanas, haviam introduzido escolas e imprensa, e estavam tão preparados como os cidadãos da Nova Inglaterra para recitar axiomas dos teóricos do commonwealth.

Foi a escravidão, quero sugerir, mais do que qualquer outro fator isolado, que fez a diferença. Foi a escravidão que permitiu à Virgínia acalentar uma sistema de governo representativo numa sociedade rural. Foi a escravidão que transformou a Virgínia do governador Berkeley na Virgínia de Thomas Jefferson. Foi a escravidão que fez os virginianos terem a coragem de falar uma linguagem política que engrandecia os direitos dos homens livres. Foi, portanto, a escravidão que trouxe os virginianos para a mesma tradição política do commonwealth da Nova Inglaterra. A mesma instituição que depois da Revolução dividiria o Norte do Sul pode ter sido o fator que possibilitou sua união num governo republicano.

Assim começou o paradoxo norte-americano da escravidão e da liberdade, entrelaçadas e interdependentes: os direitos dos ingleses apoiados sobre as injustiças contra os africanos. A Revolução Americana só tornou as contradições mais gritantes, à medida que os colonizadores senhores de escravos proclamavam para um mundo ingênuo os direitos não apenas dos ingleses mas de todos os homens. Explicar a origem das contradições, se a explicação sugerida for válida, não as elimina nem as torna menos desagradáveis. Mas talvez nos permita entender um pouco melhor a força dos vínculos que prendem a liberdade à escravidão, mesmo numa cabeça tão nobre como a de Jefferson. E talvez nos faça pensar sobre os vínculos que prendem tiranias mais tortuosas à nossa própria liberdade e que ainda nos dão hoje nosso próprio paradoxo americano.

Notas

1 Especialmente Staughton Lynd, Class conflict, and the United States constituion: ten essays. Indianapolis, 1967.

2 Curtis P. Nettels, The emergence of a national economy 1775-1815. New York, 1962, p. 19. Ver também Merrill Jensen, The American Revolution and American agriculture, Agricultural History, 43, p. 107-124, jan. 1969. 
3 William Cohen, Thomas Jefferson and the problem of slavery, Journal of American History, 56, p. 503-526, dez. 1969; D.B. Davis, Was Thomas Jefferson an authentic enemy of slavery? Oxford, 1970; Winthrop D. Jordan, White over black: American attitudes toward the negro, 1550-1812. Chappel Hill, 1968, p. 429-481.

4 Julian P. Boyd (ed.), The papers of Thomas Jefferson, 18 v. Princeton, 1950-...., X, p. 615. Para outras manifestações da aversão de Thomas Jefferson a dívidas e sua desconfiança contra o crédito, ver ibid., 2, p. 275-276; 8, p. 398-399, p. $632-633 ; 9$, p. 217-218; 472-473; 10, p. 304-305; 11, p. 472, 633, 636, 640; 12 , p. 385-386.

5 A carreira de Jefferson como embaixador na França foi em grande parte consumida por um esforço inútil de quebrar o domínio do poder inglês sobre o comércio americano.

6 Ver Caroline Roberts, The eighteenth-century commonwealthman: studies in the transmission, development and circumstance of English liberal thought from the restauration of Charles II until the war with the thirtheen colonies. Cambridge, Mass., 1959; J.G.A. Pocock, Machiavelli, Harrington, and English political ideologies in the thirteenth century, William and Mary Quarterly, 22, p. 549583 , out. 1965.

7 Boyd (ed.), Papers of Thomas Jefferson, I, p. 344, 352, 362, 560; VIII, p. 681-682.

8 Ibid., 8, p. 426, 682; Thomas Jefferson, Notes on the state of Virginia, William Peden (ed.), Chappel Hill, 1955, p. 165. Parece que Jefferson subestimou a dependência dos agricultores da Virgínia das vicissitudes e caprichos do mercado de tabaco.

9 Ver Robbins, The eighteenth-century commonwealthmen; Pocock, Machivelli, Harrington, and English political ideologies, p. 549-583; Michael Zuckerman, The social context of democracy in Massachusetts, William and Mary Quarterly, p. 523-544, out. 1968; Robert M. Weir, The harmony we were famous for an interpretation of pre-revolutionary South Caroline politics, ibid., p. 473-501, out. 1969.

10 C.B. Macpherson, The political theory of possessive individualism, Oxford, 1962, p. 221-224; H. R. Fox Bourne, The life of John Locke, 2 v., London, 1876, II, p. 377-390.

11 Adam Ferguson, The history of progress and termination of the Roman republic, 5v., Edinburgh, 1799, I, p. 384. Ver também Adam Ferguson, An essay on the history of civil society, London, 1768, p. 309-311.

12 Francis Hutcheson, A system of moral philosophy, 2 v., London, 1755, II, p. 202; David B. Davis, The problem of slavery in western culture, Ithaca, 1966, p. 374378. Devo a este autor várias sugestões preciosas. 
13 James Burgh, Political disquisitions: or an 'enquire' into public errors, defects, and abuses ..., 3 v., London, 1774-1775, III, p. 220-221. Ver a proposta do bispo George Berkeley segundo a qual "mendigos contumazes deveriam ... ser presos e transformados em escravos da comunidade durante um certo número de anos". Citado em R. H. Tawney, Religion and the rise of capitalism: a historical essay, New York, 1926, p. 270.

14 E. Millicent Sowerby (ed.), Catalogue of the library of Thomas Jefferson, 5 v., Washington, 1952-1969, I, p. 192.

15 Andrew Fletcher, Two discourses concerning the affairs of Scotland. Written in the year 1698, Edinburgh, 1698. Ver o segundo discurso, com paginação própria, p. 1-33, especialmente p. 16.

16 Boyd (ed.), Papers of Thomas Jefferson, VIII, p. 681-683.

17 Ibid., IX, p. 659-660.

18 Jackson Turner Main, The social structure of revolutionary America, Princeton, 1965 , p. 271.

19 Em 1755 a Virgínia tinha 43.329 brancos contribuintes ao pagamento da dízima e 60.078 negros. Os contribuintes incluíam homens brancos acima dos dezesseis anos de idade e mulheres e homens negros acima dessa idade. No censo de 1790, a Virgínia tinha 292.717 escravos e 110.936 rapazes brancos acima dos dezesseis anos, dentre uma população total de 747.680. Evarts B. Greene e Virginia D. Harrington, American population before the federal census of 1790, New York, 1932, p. 150-155.

20 Jefferson, Notes on the state of Virginia, p. 138.

21 Jack P. Greene (ed.), The diary of colonel London Carter of Sabine Hall, 17521778, 2 v., Charlottesville, 1965, II, p. 1055.

22 Boyd (ed.), Papers of Thomas Jefferson, XIV, p. 492-493.

23 St. George Tucker, A dissertation on slavery with a proposal for the gradual abolition of it, in the state of Virginia, Philadelphia, 1786. Ver também Jordan, White over black, p. 555-560.

24 Joan Thrisk (ed.), The agrarian history of England and Wales, v. VI, 1500-1640, Cambridge, England, 1967, p. 531.

25 Ver Edmund S. Morgan, The labor problem at Jamestown, 1607-1618, American History Review, 76, especialmente p. 600-606, jun. 1971.

26 A frase é de Richard Hakluyt. Ver E. G. R. Taylor (ed.), The original writings es correspondence of the two Richard Hakluyts, 2 v., London, 1935, I, p. 142. 
27 Richard Hakluyt, The principal navigations, voyages and discoveries of the English nation ..., London, 1589.

28 A história completa desse episódio extraordinário encontra-se em I. A. Wright (ed.), Documents concerning English voyages to the Spanish main 1569-1580, London, 1932.

29 Taylor (ed.), Original writings é correspondence, I, p. 139-146.

30 Walter Raleigh, The discoverie of the large and beawtiful Empire of Guiana, V.T. Harlow (ed.), London, 1928, p. 138-149; V.T. Harlow (ed.), Raleigh's last voyage: being an account drawn out of contemporary letters and relations..., London, 1932, p. 44-45.

31 Taylor (ed.), Original writings and correspondence II, p. 211-377, especialmente p. 318.

32 Irene A. Wright (trans. and ed.), Further English voyages to Spanish America, 1583-1594: documents from the archives of the Indies and Seville ..., London, 1951, p. lviii, lxiii, lxiv, 37, 52, 54-55, 159, 172-173, 181, 188-189, 204-206.

33 Os espanhóis relataram que "Embora seus donos estivessem dispostos a resgatálos, os ingleses não os entregariam a não ser que os próprios escravos optassem por isso". Ibid., p. 159. Na expedição seguinte de Walter Raleigh, os espanhóis notaram que os ingleses diziam aos nativos que "eles não queriam torná-los escravos, mas apenas ser seus amigos; prometendo trazer-lhes muitas machadinhas e facas, especialmente se expulsassem os espanhóis de seus territórios". Harlow (ed.), Raleigh's last voyage, p. 179.

34 David Beers Quinn (ed.), The Roanoke voyages 1584-1590, 2 v., London, 1955.

35 Morgan, The labor problem at Jamestown, 1607-18, p. 595-611; Edmund S. Morgan, The first American boom: Virginia 1618 to 1630, William and Mary Quarterly, 28, p. 169-198, abr. 1971.

36 Não há registros confiáveis da imigração, mas a presença de pessoas dessas nacionalidades é comprovada pelos registros de tribunais de condados, nos quais todos, exceto os holandeses, são identificados nominalmente como, por exemplo, "James, o escocês", ou "Cursory, o turco". Os holandeses aparentemente logo anglicizaram seus nomes e torna-se difícil idenditicá-los, a não ser em casos em que os registros revelam sua naturalidade. Os dois condados dos quais sobrevivem os registros mais completos para as décadas de 1640 e 1650 são Accomack-Northampton e Lower Norfolk. Há microfilmes desses registros na Virginia State Library em Richmond.

37 Por serem os registros remanescentes tão fragmentários, tem havido muita controvérsia sobre o status dos primeiros negros na Virgínia. O que os registros evidenciam é que nem todos eram escravos e nem todos eram livres. Ver Jordan, 
White over black, p. 71-82.

38 Para exemplos, ver Northampton County court records, deeds, wills etc., Book III, p. 38, 54, 60, 102, 117-119; York County court recods, deeds, orders, wills etc., n. 1, p. 232-234; Surrey County court records, deeds, wills etc., n. 1, p. 349; Henrico County records, deeds and wills 1677-1692, p. 139.

39 Chegou-se a esse fato pela comparação dos nomes de chefes de família na listagem anual de contribuintes para o dízimo com identificações casuais de cidadãos como negros em registros de tribunais. Os nomes chefes de família assim identificados para o ano de 1668, ano de pico durante o período para o qual dispomos de listas (1662-1677), eram: Bastian Cane, Bashaw Ferdinando, John Francisco, Susan Grace, William Harman, Philip Mongum, Francis Pane, Manuel Rodriggus, Thomas Rodriggus e King Tony. O total de famílias no condado em 1669 era de 172; os contribuintes negros escravos eram 42. Assim cerca de 29\% dos contribuintes negros, e provavelmente de todos os negros, eram livres; e cerca de $13,5 \%$ dos contribuintes eram negros.

40 Northampton deeds, wills etc., Book V, p. 54-60, 1 nov. 1654.

$41 \mathrm{O}$ número para 1625 provém do censo daquele ano, que registra 1.210 pessoas, mas provavelmente deixou de incluir cerca de $10 \%$ da população. Morgan, The first American boom, p. 170n-17ln. O número para 1640 provém da legislação que limita a produção de tabaco por pessoa de 1639-1640. Essa legislação está resumida num manuscrito pertencente a Jefferson, reproduzido em William Walter Hening, The statutes at large; being a collection of all the laws of Virginia, from the first session of the legislature, in the year 1619, (13 v., New York, 1823, I, p. 224-225, 228. O texto completo está em Acts of the general assembly, 6 de jan., p. 1639-1640, William and Mary Quaterly, IV, p. 17-35, jan. 1924 e Acts of the general assembly, 6 jan. 1639-1640, ibid., jul. de 1924, p. 159-162. A assembléia calculou que a coleta de $£ 4$ de tabaco por contribuinte totalizaria 8.584, implicando $4 . £ 1646$ contribuintes (homens com mais de 16 anos de idade). Também calcula-se que se limitando a plantação a $£ 170$ por cabeça alcançcar-se-ia o total de $£ 1.300 .000$, implicando 7.647 cabeças. É evidente que este último número refere-se à população inteira, como também se comprova com os dados de Hening, Statutes, I, p. 228.

42 No ano de 1635, o único ano para o qual dispomos de tais registros, 2.010 pessoas embarcaram para a Virgínia somente em Londres. Ver John Camden Hotten (ed.), The original list of persons of quality ..., London, 1874, p. 35-145. Para outros anos temos números casuais. Francis West mencionou que, de fevereiro de 1627 a fevereiro de $1628,1.000$ pessoas foram "recebidas ultimamente". Colonial Office Group, Class 1, Piece 4, folio 109 (Public Record Office, London), daqui em diante citado como CO 1/4, f. 109. De fevereiro de 1633 a fevereiro do ano seguinte, segundo o governador John Harvey "os recémchegados deste ano" desembarcaram "este ano". Yong a Sir Tobie Matthew, 13 
de julho de 1634, Aspinwall Papers, Massachusetts Historical Society collections, XI, 1871, p. 110. Em maio de 1635, Samuel Mathews afirmou que 2.000 chegaram "este ano". Carta de Mathews a ... ?, 25 de maio de 1635, The Mutiny in Virginia, 1635, Virginia Magazine of History and Biography, I, p. 417, abr. 1894. E em março de 1636, John West relatou que 1.606 pessoas haviam chegado "este ano". Carta de West aos membros da comissão das plantations, 28 de março de 1636, Virginia in 1636, ibid., 9 de julho 1901, p. 37.

43 O número oficial de contribuintes para o ano de 1622 era de 11.838. Clarendon Papers, 82, Oxford, Bodleian Library. A proporção de contribuintes para o total dos membros da população da época era provavelmente de cerca de um para dois. (Em 1625 era de 1 para 1,5; em 1699, de 1 para 2,7.) Uma vez que quase com certeza a estimativa oficial se situava abaixo da realidade, uma população total de aproximadamente 25 mil cidadãos parece provável. Todas os números sobre a população da Virgínia do século XVII devem ser vistos como estimativas rudimentares.

44 Provas da ocupação de terras depois de 1660 encontram-se em CO 1/39, f. 196; CO 1/40, f. 23; CO 1/48, f. 48; CO 5/1309, números 5, 9 e 23. Sloane Papers, 1008, f. 334-335, British Museum, London. Uma contagem recente de concessões de patentes para ocupação de terras na Virgínia mostra 82 mil concessões reivindicadas de 1635 a 1700 . Destas, quase 47 mil ou $57 \%$ (equivalentes a 2.350.000 acres) foram reivindicadas nos 25 anos após 1650. W.F. Craven, White, red, and black: the seventeenth-century Virginian, Charlottesville, 1971, p. 14-16.

45 Hoje não é possível obter um conjunto contínuo de números para as exportações de tabaco da Virgínia do século XVII. Os números disponíveis para a importações de tabaco americano (na maior parte proveniente da Virgínia) encontram-se no United States Bureau of the Census, Historical Statistics of the United States, Colonial Times to 1957, Washington D. C., 1960, série Z 238-240, p. 766. Mostram para o ano de 1572 um total de $£ 17.559 .000$. Em 1631 o número fora de $£$ 272.300. As safras de tabaco variavam muito de ano para ano. Dados sobre os preços são hoje quase tão difíceis de obter quanto os do volume. Os dos anos de 1667-1675 são calculados a partir dos preços correntes que se encontram em Warren Billings, Virginia's deploured condition, 1660-1676: the coming of Bacon's rebellion, dissertação de doutorado, Northen Illionois University, 1969, p. 155-159.

46 Ver abaixo.

47 Thomas Ludwell e Robert Smith ao rei, 18 de junho de 1676, v. 77, f. 128, Coventry Papers Longleat House, American Council of Learned Societies British Mss. project, rolo n. 63, Library of Congress.

48 Ibid., p. 204-205.

49 Nicholas Spencer a Lorde Culpeper, 6 de agosto de 1676, ibid., p. 170. Ver também CO l/49, f. 107. 
50 Os números derivam de amostras de nomes de pessoas para as quais foram reivindicadas concessões de patentes de terra. Patent Books I-IX, Virginia State Library, Richmond. Wyndham B. Blanton encontrou 17.350 mulheres e 75.884 homens em "uma longa pesquisa dos livros de patentes e de outros registros da época ...", uma proporção de uma mulher para 4.4 homens. Wyndham B. Blanton, Epidemics, real and imaginary, and other factors influencing seventeenth century Virginia's population, Bulletin of the History of Medicine, 31, p. 462, set./out. 1957. Ver também Craven, White, red, and black, p. 26-27.

51 Os piratas foram particularmente problemáticos nas décadas de 1680 e 1690 . Ver CO l/48, f. 71; CO 1/51, f. 340; CO l/52, f. 54; CO 1/55, f. 105-106; $\mathrm{CO} 1 / 57$, f. 300; CO 5/1311, n. 10.

$52 \mathrm{CO} 1 / 30$, f. 114-115.

$53 \mathrm{CO} \mathrm{l} / 37$, F. 35-40.

54 V. LXXVII, p. 144-146, Coventry Papers.

55 Hening, Statutes, II, p. 448-454; CO 1/42, f. 178; CO 1/43, f. 29; CO 1/44, f. 398; CO 1/47, f. 258-260; CO 1/48, f. 46; v. LXXVIII, p. 378-381, 386387, 398-399, Coventry Papers.

$56 \mathrm{CO} \mathrm{1/48} \mathrm{passim.}$

$57 \mathrm{CO} 1 / 43$, f. 359-365; CO 1/44, f. 10-62; CO 1/47, f. 261; CO 1/48, f. 8796, 100-102, 185; CO 5/1305, n. 43; CO 5/1309, n. 74.

58 Hening, Statutes, II, p. 113-114, 240.

59 Ibid., II, p. 266, 278.

60 Ibid., II, p. 116-117, 273-274, 277-278.

61 Por exemplo, James Gray, ausente por 21 dias, teve de servir mais 15 meses. Order Book 1666-1680, p. 163, Lancaster county court records.

62 Hening, Statutes, II, p. 118.

63 Order Book 1666-1680, p. 142, Lancaster county court records.

64 Hening, Statutes, II, p. 280. Descobriu-se, dizia o preâmbulo da lei, que essas pessoas "que têm pouco interesse no país, com mais freqüência tumultuam a eleição perturbando a paz de sua majestade do que com seu comportamento discreto na votação colaboram para a manutenção dela, escolhendo pessoas bem qualificadas para o desempenho de uma tarefa tão grande que lhes é confiada ...”

65 CO 1/39, f. 196; CO, 1/48, f. 48; CO 5/1309, n. 5, 9, 23; CO 5/1310, n. 83. 
66 Jordan, White over black, p. 44-98.

67 Em 1700 eles constituíam metade da mão-de-obra (pessoas trabalhando para outros homens) no condado de Surrey, único condado onde é possível verificar os números. Robert Wheeler, Social transition in Virginia tidewater, 1650-1720: the laboring household as an index, comunicação apresentada no encontro da Organization of American Historians, New Orleans, 15 de abril de 1971. O condado de Surrey ficava ao sul do rio James, uma das regiões mais pobres da Virgínia.

68 Ver as cartas da Royal African Company aos capitães de seus navios, 23 de outubro de 1701; 2 de dezembro de 1701; 7 de dezembro de 1704; 21 de dezembro de 1704; 25 de janeiro de 1704/5, T70 58, London, Public Record Office.

69 Abbot Emerson Smith, Colonists in bondage: white servitude and convict labor in America 1607-1776, Chapel Hill, 1947, p. 335. Ver também Thomas J. Wertenbaker, The planters of colonial Virginia, Princeton, 1922, p. 130-131, 134-135; Craven, White, red, and black, 17.

$70 \mathrm{CO} 1 / 45$, f. 138.

71 Hening, Statutes, II, p. 481-482, 492-493; III, p. 86-88, 102-103, 333-335, 447-462.

72 Como exemplo, ver carta de William Byrd II ao conde de Egmont, 12 julho de 1736, Elizabeth Donnan (ed.), Documents illustrative of the history of the slave trade to America, 4 v., Washington, 1930-1935, IV, p. 131-132. Mas, compare-se a carta de Byrd com Peter Beckford, 6 dezembro de 1735, Letters to the Byrd Family, Virginia Magazine of History and Biography, 36, p. 121-123, abr. 1928, onde ele especificamente nega qualquer perigo. A assembléia da Virgínia em várias ocasiões fixou taxas sobre a importação de escravos. Ver Donnan (ed.), Documents illustrative of the history of the slave trade, IV, p. 66-67, 86-88, 91-94, 102-117, 121-131, 132-142. O objetivo de algumas leis era desestimular importações, mas aparentemente o motivo era equilibrar a balança comercial depois de um período no qual os senhores de plantations compraram muito mais do que conseguiam pagar. Ver também Wertenbaker, The planters of colonial Virginia, p. 129.

73 O viajante suíço Francis Ludwig Michel observou em 1702 que "Compram-se geralmente escravos de ambos os sexos, que depois se multiplicam". William J. Hinke (trans. and ed.), Report of the journey of Francis Louis Michel from Berne Switzerland to Virginia, October, 2 (1) 1701- December 1, 1702: Part II, Virginia Magazine of History and Biography, 24, p. 116, abr. 1916. Uma amostra dos nomes identificados pelo sexo, para os quais se reivindicavam subsídios na forma de patentes de terra nas décadas de 1680 e 1690, mostra que entre os negros há uma proporção muito maior de mulheres em relação aos 
homens do que entre os brancos. Por exemplo, nos anos de 1695-1699, verifico, no Livro de Patentes 9.818 homens brancos e 276 mulheres brancas; 376 homens negros e 200 mulheres negras (mas comparem-se esse números com Craven, White, red, and black, p. 99-100). No condado de Northampton em 1667, entre 75 contribuintes negros havia 36 homens, 38 mulheres e 1 pessoa cujo sexo não é possível determinar. No condado de Surrey em 1703, entre 211 contribuintes negros havia 132 homens, 74 mulheres e 5 pessoas cujo sexo não é possível determinar. Esses são únicos condados em que temos registros de informações deste gênero. Northampton county court records, order book 10, p. 189-191; Surrey county records, deeds, wills etc., n. 5, part 2, p. 287-290.

74 A Virgínia livrou-se de tantos desse modo na campanha contra Cartagena em 1774 que alguns anos mais tarde a colônia não conseguiu juntar mais ninguém para outra expedição. Fairfax Harrison, When the convicts came, Virginia Magazine of History and Biography, 30, p. 250-260, jul. 1922, especialmente p. 256-257; John W. Shy, A new look at colonial militia, William and Mary Quarterly, 20, p. 175-185, abr. 1963. Em 1736 a Virgínia havia despachado outra leva de libertos indesejados para a Georgia por causa do boato sobre um ataque dos espanhóis. Carta de Byrd II a lorde Edmont, julho de 1736, Letters of the Byrd family, Virginia Magazine of History and Biography, 36, p. 216217 , jul. 1928. Observações de um viajante inglês que embarcou no mesmo navio sugerem que eles não viajavam espontaneamente: "nosso carregamento consistia em toda a escória da Virgínia, que fora recrutada para servir na Georgia e que estava constantemente disposta a rebelar-se, enquanto ejaculavam as mais chocantes imprecações, agourando a destruição do barco e de tudo o que estava nele". Observations in several voyages and travels in America in the year 1736, William and Mary Quarterly, XV, p. 224, abr. 1907.

75 Comparar com Lyon G. Tyler, Virginians voting in the colonial period, William and Mary Quarterly, VI, p. 3-13, jul.1887.

76 John C. Rainbolt, The alteration in the relationship between leadership and constituents in Virginia, 1660 to 1720, William and Mary Quarterly, 27, p. 411-434, jul. 1970.

77 William Berkeley a Richard Niccols, 20 de maio de 1666, 4 de maio de 1667. Manuscritos adicionais, 28, 218, f. 14-17, British Museum, London.

78 Henings, Statutes, II, p 517.

Edmundo S. Morgan é professor de História na Universidade Yale (EUA).

Tradução de Almiro Pisetta. O original - Slavery and Freedom: the American Paradox - foi publicado em The Journal of American History, v. LIX, n. 1, p. 529. 